\title{
Nitrogen Application in Arugula Culture
}

\author{
Katiane Santiago Silva Benett ${ }^{1}$, Ricardo Caldas Xavier ${ }^{1}$, Cleiton Gredson Sabin Benett ${ }^{1}$, \\ Leandro Caixeta Salomão ${ }^{2}$, Alexsander Seleguini ${ }^{3}$, Fernando Soares de Cantuario ${ }^{2} \&$ Anne Silva Martins $^{1}$ \\ ${ }^{1}$ State University of Goiás, Ipameri Campus, Ipameri, GO, Brazil \\ ${ }^{2}$ Goiano Federal Institute, Urutaí Campus, Urutaí, GO, Brazil \\ ${ }^{3}$ Triangulo Mineiro Federal University, Iturama Campus, Iturama, MG, Brazil \\ Correspondence: Cleiton Gredson Sabin Benett, Department of Agronomy, State University of Goiás, Campus \\ Ipameri, Ipameri, Goias, Brazil. Tel: 55-643-491-1556. E-mail: cleiton.benett@gmail.com
}

Received: October 11, 2018

doi:10.5539/jas.v11n2p385
Accepted: November 23, 2018 Online Published: January 15, 2019

URL: https://doi.org/10.5539/jas.v11n2p385

\begin{abstract}
Vegetable development and productivity are influenced by several factors, including the nutrient amounts available. Providing adequate nitrogen favours vegetative growth and promotes increased productivity, in addition to providing greater succulence and improving leaf quality. This work evaluated the effect of nitrogen doses and sources on arugula culture development and productivity. The experiment was conducted on the experimental farm at the State University of Goiás, Ipameri campus, in the municipality of Ipameri, Goiás state (GO). The experiment used a $2 \times 5$ factorial randomized complete block design, with two sources (normal urea and coated urea), five nitrogen doses $\left(0,60,120,180\right.$ and $240 \mathrm{~kg} \mathrm{ha}^{-1}$ of N) and four replicates. Plant height, stem diameter, leaf number, fresh shoot matter, dry shoot matter and productivity were evaluated. The results obtained here suggest that nitrogen sources do not influence arugula culture development, but nitrogen doses influence the arugula culture's productive characteristics.
\end{abstract}

Keywords: Eruca sativa L., fertilization, production

\section{Introduction}

Arugula has been gaining prominence in many salad preparations by imparting dark green colour and unrivalled flavor. In addition, it is rich in antioxidants and minerals.

Arugula's popularity is due to the distinctive aroma and spicy taste of its leaves, which are used to decorate and complement salads, snacks and various dishes. In India, arugula seed is used as a source of oil and has several purposes in traditional herbal medicine (Harder et al., 2005). Arugula is well known in the southern and south-eastern states of Brazil but is currently cultivated and consumed in all regions (Henz \& Mattos, 2008).

Arugula cultures have more value from November to April when they reach peak demand, but production is difficult due to environmental factors such as high rainfall. To obtain vegetables in high quantity, quality and regularity, productive cropping systems are needed (Nascimento et al., 2017).

Nitrogen $(\mathrm{N})$ has a structural function, being a constituent of proteins, nitrogenous bases, amino acids, and various enzymes and energy transfer materials such as ADP, ATP and chlorophyll. It is also responsible for ionic absorption, photosynthesis, respiration and cell differentiation (Malavolta et al., 1997). Some vegetable species require high nitrogen availability, thus requiring high doses of nitrogen fertilizers throughout the leafy vegetable growing cycle (Zago et al., 2008). Therefore, determining the most appropriate application method is necessary because this affects $\mathrm{N}$ behaviour in the soil and its efficiency for crops. Some alternatives for increasing its efficiency include splitting the recommended dose or using sources with slow or controlled nutrient release.

Slow-release fertilizers present changes in the nitrogen compound structure or are coated with poorly permeable materials, thus yielding slower dissolution properties in the soil (Vitti \& Reirinchs, 2007). In this way, these fertilizers reduce $\mathrm{N}$ loss, which often happens with the use of urea, causing a physical barrier that prevents the soluble forms from exposing the nutrient to the medium, thus avoiding losses (Civardi et al., 2011).

Studies on the use of polymer-coated urea compared with normal urea in leafy vegetable fertilizers are new; thus, these fertilizers must be studied to reduce $\mathrm{N}$ losses in cultivating this vegetable crop. Fertilization programs can contribute significantly to success of the vegetable production chain and hence there is need for more 
information on using these cultivation techniques, as they will result in higher quality leaves. Hence this work evaluated the effect of nitrogen sources and doses on arugula culture, development and productivity.

\section{Materials and Methods}

\subsection{Location}

This experiment was conducted on the experimental farm of the State University of Goiás, Ipameri Campus, located in the municipality of Ipameri, Goiás state (GO) at $17^{\circ} 43^{\prime}$ south latitude, $48^{\circ} 22^{\prime}$ west longitude and 800-m altitude. The region's climate is defined as tropical (Aw), consisting of a dry season in the winter, per the classification of Köppen-Geiger (Cardoso et al., 2014). The soil at the experimental site was classified as dystrophic red-yellow Latosol (Santos et al., 2013).

The physical and chemical attributes of the soil were determined before starting the experiment as per the methodology proposed by Ribeiro et al. (1999), with the following chemical attributes in the 0.0-0.20 m layer: $19 \mathrm{mg} \mathrm{dm}^{-3}$ of P (Melich); $30 \mathrm{~g} \mathrm{dm}^{-3}$ of M.O.; $5.3 \mathrm{pH}\left(\mathrm{CaCl}_{2}\right)$; K, Ca, $\mathrm{Mg}$ and $\mathrm{H}+\mathrm{Al}$ of 3.9, 35.0, 11.0 and 28.0 $\mathrm{mmol}_{\mathrm{c}} \mathrm{dm}^{-3}$, respectively, and $64 \%$ base saturation. The physical attributes were clay: $390 \mathrm{~g}$, silt: $97 \mathrm{~g}$ and sand: $513 \mathrm{~g}$.

\subsection{Statistical Design and Plant Materials}

The experiment used a $2 \times 5$ factorial randomized complete block design, with two sources (normal urea and coated urea), five nitrogen doses $\left(0,60,120,180\right.$ and $240 \mathrm{~kg} \mathrm{ha}^{-1}$ of $\left.\mathrm{N}\right)$ and four replicates. Normal urea $(46 \% \mathrm{~N})$ and coated urea $(48 \% \mathrm{~N})$ were used as the $\mathrm{N}$ source. The $\mathrm{N}$ doses were applied as top-dressing and split at at 7 , 14 and 21 days after emergence (DAE). Cultivated arugula was the cultivar used.

Arugula was sown directly onto the beds using a spacing of $0.20 \times 0.05 \mathrm{~m}$. Experimental plots consisted of four spaced rows with lengths of $1.0 \mathrm{~m}$ each. The two central lines of each plot were considered the usable area. The sowing was fertilized at the time of planting, where 20,80 and $60 \mathrm{~kg} \mathrm{ha}^{-1}$ of $\mathrm{N}, \mathrm{P}_{2} \mathrm{O}_{5}$ and $\mathrm{K}_{2} \mathrm{O}$, respectively, were used. Cultural treatments and weed and phytosanitary control were carried out per the recommendations for arugula culturing. Water was supplied through a conventional sprinkler irrigation system.

\subsection{Evaluated Characteristics}

The following characteristics were evaluated at the first cut and $1^{\text {st }}$ and $2^{\text {nd }}$ regrowth: plant height, distance between the leaf apex and neck base, stem diameter, measured at the neck base, leaf number, fresh shoot matter, dry shoot matter collected and dried in a forced air oven at $65{ }^{\circ} \mathrm{C}$ until reaching a constant weight; all of the above in 10 plants in useful plot areas and productivity as quantity of leaves produced in the useful plot areas in $t$ $\mathrm{ha}^{-1}$.

\subsection{Statistical Analysis}

The data were analysed by analysis of variance ( $\mathrm{F}$ test), and the means were compared by Tukey's test at $5 \%$ probability for the sources. Statistical analyses were performed using the Sanest statistical analysis program and regression analysis was performed when the doses were significant.

\section{Results and Discussion}

Evaluating nitrogen fertilization's effect on the arugula cultivar showed that the average values for plant height, stem diameter, leaf number, fresh shoot mass, dry shoot mass and productivity did not significantly interact with the coated urea or normal (conventional) urea applications (Tables 1, 2 and 3).

\subsection{Evaluated Characteristics at the First Cut}

For plant height, stem diameter, fresh shoot mass and dry shoot mass, (Table 1) the plants fertilized with coated urea presented higher values but did not differ from those fertilized with normal urea. Costa et al. (2011) and Dantas and Torres (2010) obtained maximum plant heights of 27.5 and $21.75 \mathrm{~cm}$ at 37 and 36 days after sowing, respectively. 
Table 1. Mean values of plant height (PH), stem diameter (SD), leaf number (LN), shoot fresh matter (SFM), shoot dry matter (SDM) and productivity (PROD) at the first cut depending on the nitrogen sources in the arugula culture. Ipameri, GO, Brazil

\begin{tabular}{|c|c|c|c|c|c|c|}
\hline Sources & $\mathrm{PH}$ & $\mathrm{SD}$ & $\mathrm{LN}$ & SFM & SDM & PROD \\
\hline & $\mathrm{cm}$ & $\mathrm{mm}$ & - & ---------- & S ------------------- & $\mathrm{tha}^{-1}$ \\
\hline Coated urea & $13.81 \mathrm{a}$ & $2.71 \mathrm{a}$ & $5.70 \mathrm{a}$ & $50.83 \mathrm{a}$ & $12.78 \mathrm{a}$ & $6.78 \mathrm{a}$ \\
\hline Normal urea & $13.06 \mathrm{a}$ & $2.66 \mathrm{a}$ & $5.75 \mathrm{a}$ & $51.12 \mathrm{a}$ & $12.65 \mathrm{a}$ & $6.60 \mathrm{a}$ \\
\hline F Value & 2.901 & 0.109 & 0.039 & 0.004 & 0.106 & 0.075 \\
\hline $\mathrm{CV}(\%)$ & 10.43 & 16.00 & 12.56 & 26.85 & 9.52 & 30.91 \\
\hline
\end{tabular}

Note. Means followed by the same letter in the column, for each factor studied, do not differ among themselves by the Tukey test at $5 \%$ probability.

For the number of leaves per plant, both treatments presented similar leaf quantities with no differences between them. For the nitrogen dose effects, plant height increased linearly (Figure 1A) with increasing nitrogen rates, regardless of the fertilizers used. The same occurred for the number of arugula leaves per plant with respect to the dose of N (Figure 1B). These results are similar to those of Benett et al. (2015) who observed a linear increase in plant height and leaf number as the nitrogen doses increased.

The plant height results differed from those of Barros Junior (2008), who showed a quadratic polynomial fit where increasing the $\mathrm{N}$ doses to the arugula resulted in increased plant heights up to $29.91 \mathrm{~cm}$, obtained using $119 \mathrm{~kg} \mathrm{ha}^{-1}$ of $\mathrm{N}$. Trani et al. (1994) also observed a quadratic polynomial fit for arugula plant height, obtaining $21.7 \mathrm{~cm}$ plants using $209 \mathrm{~kg} \mathrm{ha}^{-1}$ of $\mathrm{N}$.
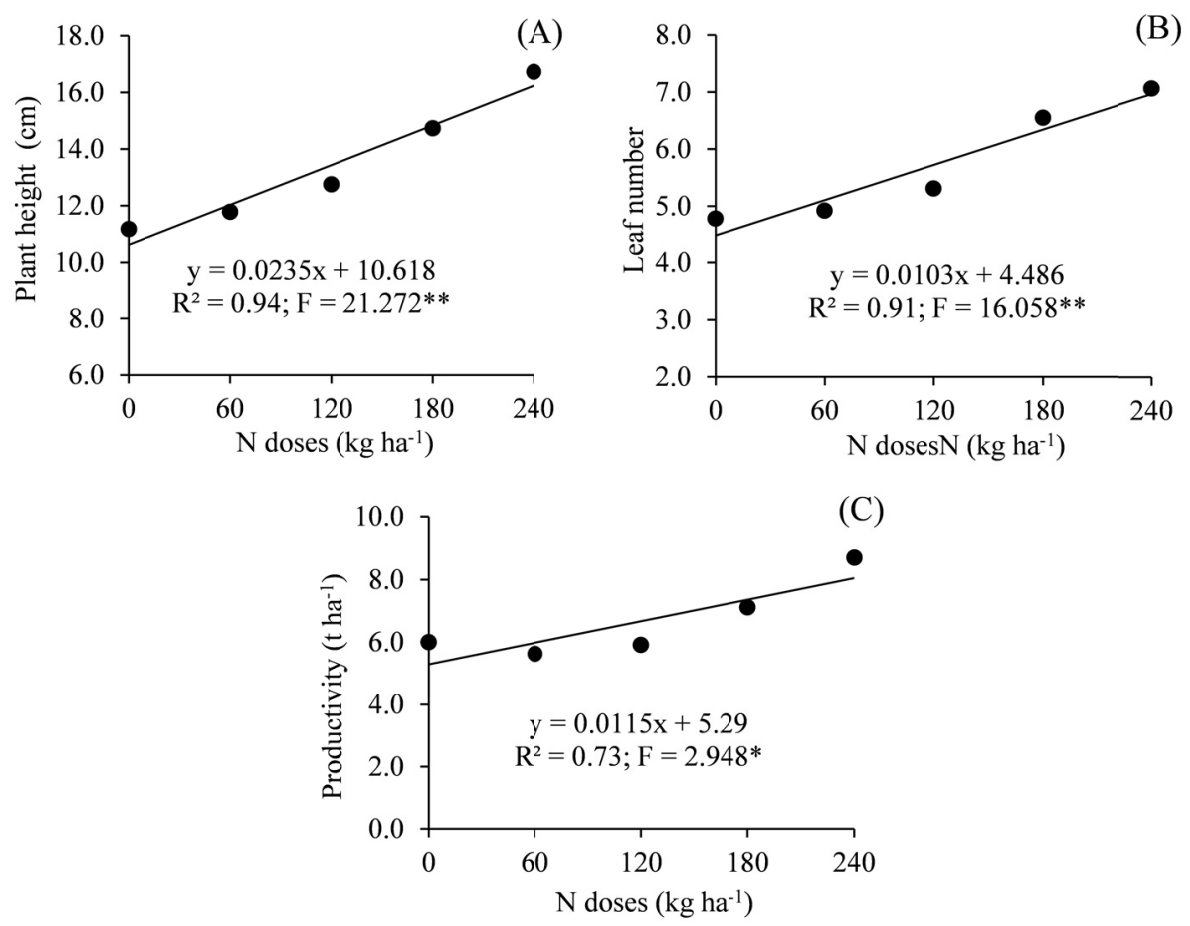

Figure 1. Values of plant height (A), leaf number (B) and productivity $(\mathrm{C})$ as a function of nitrogen dose in arugula. Ipameri, GO, Brazil. *;** = significant at 5 and $1 \%$ probability, respectively

For the fresh and dry shoot masses, however, no significant effects were observed for the nitrogen doses since the number of leaves may vary depending on the mass ratio. These results differ from those obtained by Purquerio et al. (2007), who fit the data to quadratic polynomial regression with increased dry shoot mass and increasing $\mathrm{N}$ doses up to the estimated dose of $198.5 \mathrm{~kg} \mathrm{ha}^{-1}$. These results also differed from those of Steiner et 
al. (2011) who obtained quadratic polynomial responses for the fresh shoot mass, in which the maximum arugula production was obtained by applying $160 \mathrm{mg} \mathrm{dm}^{-3}$ of $\mathrm{N}$ as urea.

When evaluating arugula productivity (Figure 1C), it increased with increasing nitrogen rates linearly, and their data fit a positive linear regression. These results differed from those of Benett et al. (2015), where the nitrogen rates were fit to quadratic regression with a maximum point of $187 \mathrm{~kg} \mathrm{ha}^{-1}$ of $\mathrm{N}$ for the first crop.

\subsection{Evaluated Characteristics in $1^{a}$ Regrowths}

When the first arugula regrowth was evaluated, the results were similar to those of the first cut. No statistical differences were observed between the variables when using different fertilizer sources (Table 2); however, the values for plant height, stem diameter, dry shoot mass and yield were higher when urea was coated.

Table 2. Mean values of plant height (PH), stem diameter (SD), leaf number (LN), shoot fresh matter (SFM), shoot dry matter (SDM) and productivity (PROD) of $1^{\mathrm{a}}$ regrowth depending on the nitrogen sources in the arugula culture. Ipameri, GO, Brazil

\begin{tabular}{lllllll}
\hline Sources & PH & SD & LN & SFM & SDM & PROD \\
\hline & $\mathrm{cm}$ & $\mathrm{mm}$ & - & $-1.0-0.0$ & $\mathrm{t}^{-1}$ \\
Coated urea & $14.98 \mathrm{a}$ & $2.81 \mathrm{a}$ & $4.82 \mathrm{a}$ & $51.80 \mathrm{a}$ & $14.83 \mathrm{a}$ & $2.77 \mathrm{a}$ \\
Normal urea & $14.37 \mathrm{a}$ & $2.95 \mathrm{a}$ & $5.08 \mathrm{a}$ & $53.74 \mathrm{a}$ & $14.21 \mathrm{a}$ & $2.61 \mathrm{a}$ \\
\hline F Value & 3.888 & 2.668 & 4.002 & 0.340 & 1.506 & 0.908 \\
\hline CV $(\%)$ & 6.66 & 9.73 & 8.30 & 19.99 & 10.99 & 19.97 \\
\hline
\end{tabular}

Note. Means followed by the same letter in the column, for each factor studied, do not differ among themselves by the Tukey test at $5 \%$ probability.

For $\mathrm{N}$ doses, plant height (Figure 2A) and leaf number (Figure 2B) showed significant effects for which the data were fit to a quadratic polynomial regression with estimated maximum points of 253.6 and $181.8 \mathrm{~kg} \mathrm{ha}^{-1}$, respectively. In this way we can affirm that rucula plants are strongly influenced by nitrogen fertilization.
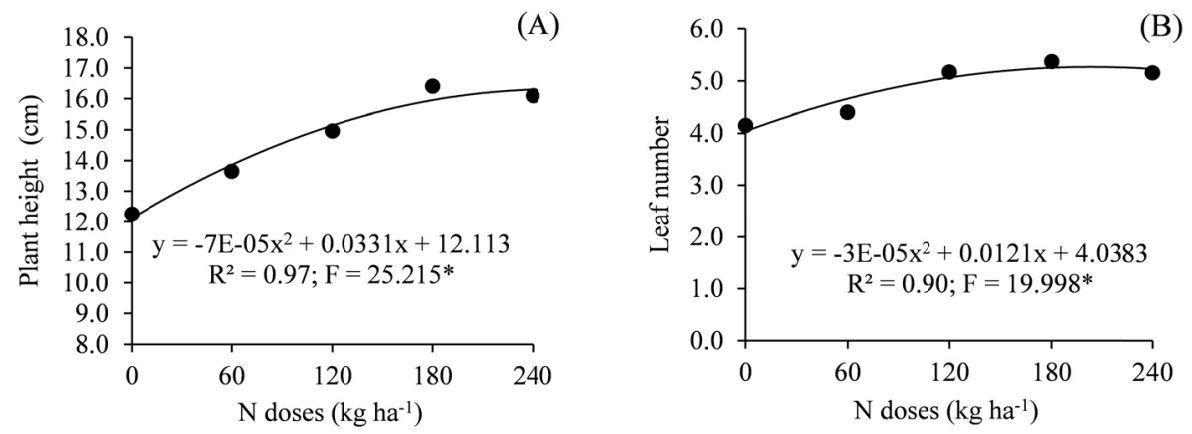

Figure 2. Values of plant height (A), number of leaves (B) of $1^{\mathrm{a}}$ regrowth as function of nitrogen doses in cover in the arugula culture. Ipameri, GO, Brazil. * = significant at $5 \%$ probability

The plant height results differed from those of Carvalho et al. (2012), who evaluated the number of arugula leaves and obtained a linear response as a function of the nitrogen doses.

\subsection{Evaluated Characteristics in $2^{a}$ Regrowths}

Table 3 presents the evaluation results for arugula after the third cut (second regrowth). Similar to the first cut, no significant interaction effect occurred between the sources and doses evaluated, nor were any effects observed for the sources used on arugula development and productivity in the second harvest (Table 3). These results differ from those of Ratke et al. (2011), who observed that fresh shoot mass increased in a quadratic form with a maximum point of $600 \mathrm{~kg} \mathrm{ha}^{-1}$ when working with nitrogen fertilization in arugula cultivation. 
Table 3. Mean values of plant height (PH), stem diameter (SD), leaf number (LN), shoot fresh matter (SFM), shoot dry matter (SDM) and productivity (PROD) of $2^{\mathrm{a}}$ regrowth depending on the nitrogen sources in the arugula culture. Ipameri, GO, Brazil

\begin{tabular}{lllllll}
\hline Sources & PH & SD & LN & SFM & SDM & PROD \\
\hline & $\mathrm{cm}$ & $\mathrm{mm}$ & - & -1.00 & $\mathrm{t} \mathrm{ha}^{-1}$ \\
Coated urea & $15.00 \mathrm{a}$ & $2.77 \mathrm{a}$ & $4.25 \mathrm{a}$ & $44.88 \mathrm{a}$ & $8.99 \mathrm{a}$ & $2.15 \mathrm{a}$ \\
Normal urea & $14.74 \mathrm{a}$ & $2.80 \mathrm{a}$ & $4.40 \mathrm{a}$ & $45.58 \mathrm{a}$ & $8.67 \mathrm{a}$ & $2.01 \mathrm{a}$ \\
\hline F Value & 0.360 & 0.060 & 1.746 & 0.1008 & 1.549 & 1.114 \\
\hline CV $(\%)$ & 9.21 & 11.55 & 8.30 & 15.54 & 9.31 & 20.00 \\
\hline
\end{tabular}

Note. Means followed by the same letter in the column, for each factor studied, do not differ among themselves by the Tukey test at $5 \%$ probability.

For $\mathrm{N}$ doses, significant effects were found for plant height, stem diameter and productivity (Figure 3). Plant height data (Figure 3A) were similar to those observed in the first crop and fit to a quadratic polynomial regression with a maximum point estimated at $222.6 \mathrm{~kg} \mathrm{ha}^{-1}$ of $\mathrm{N}$. While for stem diameter (Figure 3B) and productivity (Figure 3C), the data fit a positive linear regression. These results differed from those of Purqueiro et al. (2007), who verified a significant effect for productivity of up to $240 \mathrm{~kg} \mathrm{ha}^{-1}$ of $\mathrm{N}$ in the winter crop.

In this case, the productivity is related to the height of the plant, and the leaves are used completely, so the higher the height of the plant the greater the volume in the foliar area will be for this crop and the variety used.
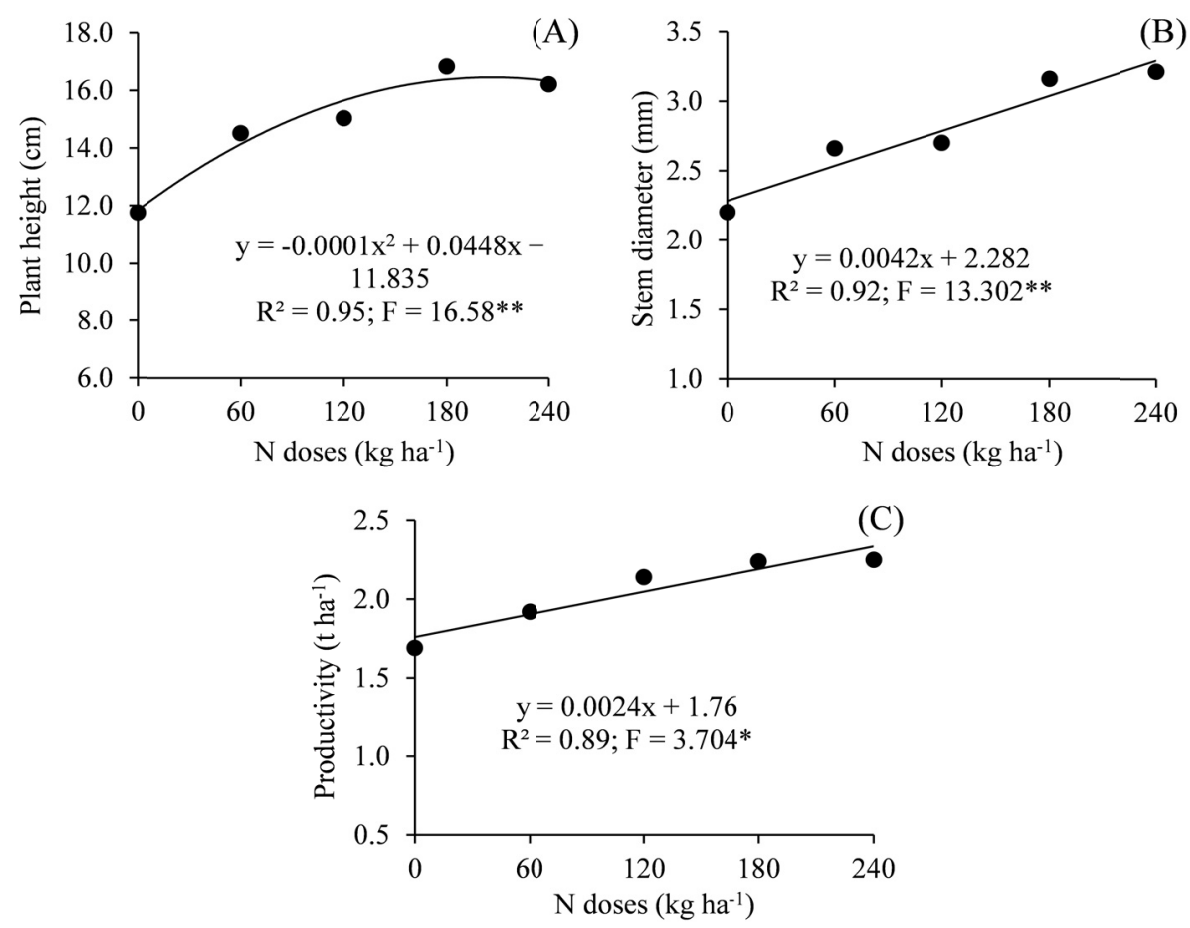

Figure 3. Values of plant height (A), stem diameter (B) and productivity (C) of $2^{\mathrm{a}}$ regrowth as function of nitrogen doses in arugula culture. Ipameri-GO. ${ }^{*}, * *=$ significant at 5 and $1 \%$ probability, respectively

\section{Conclusion}

Considering the results obtained here, nitrogen sources did not influence arugula development; however, the nitrogen rates influenced the arugula culture's productivity characteristics positively. 


\section{Acknowledgments}

To the State University of Goiás (Universidade Estadual de Goiás) (UEG), Campus Ipameri, for the support in the conduction of the project, for the productivity bag PROBIP to the first author and to Group of Study and Research in Plant Science (GEPFi).

To the Goiano Federal Institute (Instituto Federal Goiano) (IF Goiano), Campus Urutaí for financial support.

\section{References}

Barros Junior, A. P. (2008). Adubação nitrogenada no consórcio alface e rúcula (p. 104). Jaboticabal: UNESP..

Benett, K. S. S., Benett, C. G. S., Santos, G. G., \& Costa, E. (2015). Effects of hydrogel and nitrogen fertilization on the production of arugula in successive crops. African Journal of Agricultural Research, 10(26), 2601-2607. https://doi.org/10.5897/AJAR2015.9709

Cardoso, M. R. D., Marcuzzo, F. F. N., \& Barros, J. R. (2014). Classificação climática de Köppen-Geiger para o Estado de Goiás e o Distrito Federal. ACTA Geográfica, 8(16), 40-55.

Carvalho, K. S, Bonfim-Silva, E. M, Silveira, M. H. D, Cabral, C. E. A., \& Leite, N. (2012). Rúcula submetida à adubação nitrogenada via fertirrigação. Enciclopédia Biosfera, 8(15), 1545-1553.

Costa, C. M. F, Seabra Júnior, S., Arruda, G. R., \& Souza, S. B. S. (2011). Desempenho de cultivares de rúcula sob telas de sombreamento e campo aberto. Semina: Ciências Agrárias, 32(1), 93-102. https://doi.org/ 10.5433/1679-0359.2011v32n1p93

Civardi, E. A, Neto, A. N. S., Ragagnin, V. A, Godoy, E. R., \& Brod, E. (2011). Ureia de liberação lenta aplicada superficialmente e uréia comum incorporada ao solo no rendimento do milho. Pesquisa Agropecuária Tropical, 41(1), 52-59. https://doi.org/10.5216/pat.v41i1.8146

Dantas, M. R. S., \& Torres, S. B. (2010). Vigor de sementes de rúcula e desempenho das plantas em campo. Revista Brasileira de Sementes, 32(4), 049-057. https://doi.org/10.1590/S0101-31222010000400006

Harder, W. C., Zárate, N. A. H., \& Vieira, M. C. (2005). Produção e Renda Bruta de Rúcula (Eruca Sativa Miller) 'Cultivada' e de Almeirão (Cichorium intybus L.) 'Amarelo' em Cultivo Solteiro e Consorciado. Ciência e Agrotecnologia, 29(4), 775-785. https://doi.org/10.1590/S1413-70542005000400009

Henz, G. P., \& Mattos, L. M. (2008). Manuseio pós-colheita de rúcula (p. 7, Comunicado Técnico 64). Brasília-DF: Embrapa Hortaliças.

Malavolta, E., Vitti, C. G., \& Oliveira, S. A. (1997). Avaliação do estudo nutricional das plantas: Princípios e aplicações (p. 319). Piracicaba-SP: Potafós.

Nascimento, M. V., Silva Junior, R. L., Fernandes, L. R., Xavier, R. C., Benett, K. S. S., Seleguini, A., \& Benett, C. G. S. (2017). Manejo da adubação nitrogenada nas culturas de alface, repolho e salsa. Revista de Agricultura Neotropical, 4(1), 65-71. https://doi.org/10.32404/rean.v4i1.1099

Purquerio, L. F. V., Demant, L. A. R., Goto, R., \& Villas Boas, R. L. (2007). Efeito da adubação nitrogenada de cobertura e do espaçamento sobre a produção de rúcula. Horticultura Brasileira, 25(3), 464-470. https://doi.org/10.1590/S0102-05362007000300028

Ratke, R. F., Verginassi, A., Basto, D. C., Morgado, H. S., Souza, M. R. F., \& Fernandes, E. P. (2011). Production and levels of foliar nitrogen in rocket salad fertilized with controlled-release nitrogen fertilizers and urea. Horticultura Brasileira, 29(2), 246-249. https://doi.org/10.1590/S0102-05362011000200020

Ribeiro, A. C., Guimarães, P. T. G., \& Alvarez, V. H. (1999). Recomendações para o uso de corretivos e fertilizantes em Minas Gerais - $5^{a}$ aproximação (p. 359). Viçosa: UFV.

Santos, H. G., Jacomine, P. K. T., Anjos, L. H. C., Oliveira, V. A., Lumbreras, J. F., Coelho, M. R., ,.. Oliveira, J. B. (2013). Sistema brasileiro de classificação de solos (3rd ed., p. 353). Brasília-DF: Embrapa.

Steiner, F., Pivetta, L.A., Castoldi, G., Pivetta. L. G., \& Fiorenze, L. F. (2011). Produção de rúcula e acúmulo de nitrato em função da adubação nitrogenada. Revista Brasileira de Ciências Agrárias, 6(2), 230-235. https://doi.org/10.5039/agraria.v6i2a950

Trani, P. E., Granja, N. P., Basso, L. C., Dias, D. C. F. S., \& Minami, K. (1994). Produção e acúmulo de nitrato pela rúcula afetados por doses de nitrogênio. Horticultura Brasileira, 12(1), 25-29. 
Vitti, G. C., \& Reirinchs, R. (2007). Formas tradicionais e alternativas de obtenção e utilização do nitrogênio e do enxofre: Uma visão Holística. In T. Yamada, S. R. Stipp, \& G. C. Vitti (Eds.), Nitrogênio e Enxofre: na agricultura brasileira (pp. 109-157). Piracicaba: IPNI.

Zago, V. C. P., Evangelista, M. R., Almeida, D. I., Guerra, J. G. M., Rumjanek, N. G., \& Neves, M. C. P. Influência de diferentes fontes e doses de adubos nitrogenados nos teores de n-nitrato e na produtividade de alface. Scientia Agraria Paranaenses, 7(1-2), 15-24.

\section{Copyrights}

Copyright for this article is retained by the author(s), with first publication rights granted to the journal.

This is an open-access article distributed under the terms and conditions of the Creative Commons Attribution license (http://creativecommons.org/licenses/by/4.0/). 